\title{
The status of cryptosporidiosis in Jordan: a review
}

AbdelRahman Zueter ${ }^{1}$

${ }^{1}$ Department of Medical Laboratory Sciences, The Hashemite University, Zarqa, Jordan. (Correspondence to: AbdelRahman Zueter: zeuterabdelrahman@gmail.com).

\begin{abstract}
Background: Cryptosporidium is a waterborne intestinal parasite that causes diarrhoea in low and middle-income countries worldwide. Reports from Mediterranean countries have documented the prevalence of cryptosporidiosis in children at various ages, also among cancer patients, and in cases of chronic kidney disease, haemodialysis, and organ transplant. Untill now, modified-acid staining preceded by stool concentration preparation remains the leading screening diagnostic test for the infection. In Jordan, few studies for cryptosporidiosis have been performed during the last 3 decades.
\end{abstract}

Aims: This paper reviewed the status of cryptosporidiosis in Jordan and tracked recent updates for this emerging protozoal infection among different population groups.

Methods: In this study, an online search was conducted on Google Scholar and PubMed databases using the keywords: Jordan, cryptosporidiosis and Cryptosporidium to inspect studies done on this parasite in Jordan.

Results: Only 9 articles were identified from 1994 to 2019. These were analysed in terms of population group, demography, clinical history and the diagnostic tools used.

Conclusion: Cryptosporidiosis is still neglected in Jordan as indicated by the low number of studies over the last 3 decades and the prevalence is diverse depending on the diagnostic test used and socioeconomic status.

Keywords: cryptosporidiosis, Jordan, diagnostic tools, identification

Citation: Zueter A. The status of cryptosporidiosis in Jordan: a review. East Mediterr Health J. 2020;26(12):1565-1569. https://doi.org/10.26719/ emhj.20.065

Received: 27/09/19; accepted: 18/12/19

Copyright @ World Health Organization (WHO) 2020. Open Access. Some rights reserved. This work is available under the CC BY-NC-SA 3.0 IGO license (https://creativecommons.org/licenses/by-nc-sa/3.o/igo).

\section{Background}

Cryptosporidium spp. are intracellular parasites of principal concern, especially in some Mediterranean countries with limited resources and in communities with low socioeconomic status $(1,2)$. Globally, cryptosporidiosis has been ranked as the sixth most important foodborne parasitic infection of humans and domestic animals (3).

Human cryptosporidiosis was first reported in 1976; after that, it was identified as the major cause of chronic diarrhoea in HIV-positive patients and children and as a cause of zoonotic and waterborne diarrhoeal outbreaks (4). Later, Cryptosporidium infection prevalence was seen to be on the rise among malnourished children and a cause of premature death in low-resource settings (5-7). Cryptosporidium is acquired mainly via contaminated water and the ingested oocysts cause gastrointestinal symptoms before being shed in the stool and transmitted to another host via the faecal-oral route (8). Cryptosporidiosis causes acute diarrhoea in children (9), immunocompromised patients (3), cancer patients (10) and haemodialysis patients $(11,12)$. The infection is usually self-limiting in immunocompetent individuals, however, it might be life-threatening in immunocompromised patients (2). The prevalence of cryptosporidiosis varies among different patient groups and this has been attributed to the endemicity of the parasitic infection in the region of sampling along with environmental, climatic and sanitary factors (13).
Microscopic examination of stool using acidfast staining, with or without stool concentration, is the most frequently applied screening technique for cryptosporidiosis. Acid-fast staining microscopy is cheap and accessible in poor rural settings; it is the best parasitological method in terms of sensitivity and specificity (14) and shows good performance when compared with immunological and molecular methods (15).

In Jordan, Cryptosporidium has been investigated either alone or along with other intestinal parasites in various population groups $(10,16)$, in the environment (17) and in domestic animals (18). Prevalence ranges from $4 \%$ to $19 \%$. Modified acid-fast staining microscopy has frequently been used as the diagnostic method of choice. Cryptosporidiosis risk factors have been reported in Jordan, including drinking groundwater that is exposed to contamination from sewage (17), immunosuppression (10), contact with domestic animals and eating unwashed vegetables $(19,20)$.

This paper reviews the status of cryptosporidiosis in Jordan and tracks recent updates for this emerging protozoal infection among different population groups.

\section{Literature review}

The search was performed on Google Scholar and $\mathrm{Pu}$ bMed databases using the keywords: Jordan, cryptosporidiosis and Cryptosporidium. Only 9 articles were identified from 1994 until 2019 and were downloaded; 
this reflects the scarcity of studies on this parasite in Jordan.

The first study was published in 1994, it reported on the prevalence of various parasites in elementary school children in northern Jordan. Using various parasitological methods, Cryptosporidium spp. was detected in 40 out of 1000 stool specimens collected from symptomatic and asymptomatic elementary school children aged 6-14 years in northern Jordan (16). The same study reported a higher infection rate in the younger age group ( $<9$ years) than among children in the older age group, and a higher infection rate in villages than in cities. (16).

After that, and consistent with previous results relating to Cryptosporidium prevalence, the same author further explored cryptosporidiosis in pre-school children (less than 6 years old) who suffered from symptoms of gastroenteritis and who were living in Irbid city, $85 \mathrm{~km}$ north of Amman, the capital of Jordan (20). In this study, Cryptosporidium oocysts were investigated using the formalin-ether concentration technique and cold acidfast staining followed by microscopy. Cryptosporidium oocysts were detected in $6.7 \%$ (20 out of 300 ) of the stool specimens collected from patients; 7/20 were also infected with other pathogens. Risk factors did not differ from those reported previously (16). However, it was noticed that breastfed children had a lower infection rate than those weaned early and those who were bottle-fed; this was attributed to passive maternal immunity as well as reduced exposure to contaminated water during bottle preparation (20).

Another study was done to explore different intestinal parasites associated with diarrhoea in a rural area in the northeast of Jordan. The researchers collected 200 stool samples from patients with symptomatic gastroenteritis and these were examined using a number of parasitological methods including formalin-ethyl acetate concentration, wet preparation and modified acid-fast staining. Diagnosis revealed the oocysts of
Cyclospora spp. and Cryptosporidium spp., Entamoeba histolytica, Giardia lamblia, Blastocystis hominis, Endolimax nana, Hymenolepis nana and Ascaris lumbricoides. Bacteria and other enteropathogens were also identified, including Salmonella spp., Shigella spp. and Escherichia coli. Oocysts of Cryptosporidium spp. were observed in the samples from $16(8 \%)$ patients, distributed as follows: 10 in children $\leq 14$ years old (mean 7.5 years) and 6 in adults $15-87$ years (mean 51 years). Statistically significant risk factors for the infection were related to the source of drinking water, contact with animals and eating unwashed vegetables (19).

Ten years later, 2 studies were published from the same northern city; the first focused on drinkingwater as a source of infection (17), while the second study explored diagnostic methods, children groups, infection seasonality and source of drinking water (14). Abo-Shehada et al. concluded that private groundwater reservoirs northern Jordan were significant enhancing risk factors for contamination with $C$. parvum in rural villages (17). They postulated the source of contamination was sewage disposal systems that were constructed near water reservoirs, which increased the risk of the leakage of their contents to be absorbed by the soil. Consequently, there is a health hazard through the contamination of drinking water stored in underground reservoirs. Therefore, the underground location of water reservoirs must be considered to avoid groundwater-faecal contamination.

Another survey was done to investigate for cryptosporidiosis among children from birth to 12 years at a hospital in Irbid (14). A single stool sample was collected from 300 children, 7 of whom were under chemotherapy treatment for cancer. This study compared several diagnostic methods, including direct wet mount microscopy, flotation concentration, cold Kinyoun Ziehl-Neelsen stain and direct immunofluorescence. Oocysts were detected in 112 samples using direct

\begin{tabular}{|c|c|c|c|c|}
\hline Country & Population group & Diagnostic method & Prevalence (\%) & Reference \\
\hline Libya & $\begin{array}{l}\text { Diarrhoeal patients } \\
\text { aged 2-17 years }\end{array}$ & $\begin{array}{l}\text { Lugol's iodine, } \\
\text { immunofluorescence } \\
\text { assay }\end{array}$ & 4 & 22 \\
\hline Egypt & Children aged $\leq 8$ years & Nested-PCR & 1.4 & 23 \\
\hline Lebanon & Schoolchildren & $\begin{array}{l}\text { Modified Ziehl-Neelsen } \\
\text { staining and nested- } \\
\text { PCR }\end{array}$ & 10.4 & 24 \\
\hline Palestine & $\begin{array}{l}\text { Gastroenteritis patients } \\
\text { (outbreak) }\end{array}$ & $\begin{array}{c}\text { Malachite green } \\
\text { negative staining and } \\
\text { nested-PCR }\end{array}$ & All $^{\mathrm{a}}$ & 25 \\
\hline Egypt & $\begin{array}{c}\text { Adult } \\
\text { immunocompetent } \\
\text { diarrhoeal patients }\end{array}$ & $\begin{array}{c}\text { Modified Ziehl-Neelsen } \\
\text { stain, sandwich ELISA, } \\
\text { nested-PCR }\end{array}$ & 21 & 26 \\
\hline Egypt & Haemodialysis patients & $\begin{array}{l}\text { Cold modified Ziehl- } \\
\text { Neelsen staining }\end{array}$ & 40 & 13 \\
\hline
\end{tabular}

$P C R=$ polymerase chain reaction.

ELISA = enzyme-linked immunosorbent assay.

${ }^{a}$ Cryptosporidium detected in all outbreak cases. 
immunofluorescence, which showed the highest sensitivity and specificity, $100 \%$ and $98 \%$, respectively. A higher incidence rate was recorded during the rainy season (January-May). Also, C. parvum was detected in the stools of 4 among the 7 paediatric oncology patients, suggesting an association of immune status as a risk factor (14). Overall, these results concur with previous studies which indicated that contaminated drinking water is a main source for the infection as well as the increased incidence rate among rural areas $(17,19,20)$.

Molecular epidemiology has been extensively studied in the current decade to inspect common and new genotypes of Cryptosporidium spp. in Jordan for a better understanding of the pathogen distribution, pathogenesis and transmission. Hijjawi et al. (21) genotyped 44 Cryptosporidium isolates from Jordanian children at the 18S rRNA locus and identified 4 Cryptosporidium spp.: $C$. parvum $(n=22), C$. hominis $(n=20), C$. meleagridis $(n=1)$ and $C$. canis $(n=1)$. Furthermore, subtyping for 29 isolates at the 60-kDa glycoprotein (GP60) locus revealed several rare and novel subtypes indicating unique endemicity and transmission of Cryptosporidium in Jordan. The same study showed that quantitative polymerase chain reaction (qPCR) increased the sensitivity of detection and confirmed the prevalence of the infection at up to $19 \%$ instead of the $1.8 \%$ that was obtained using microscopy.

Another genotyping study expanded the targeted populations to include several kinds of animals besides humans since associations of animals as a probable risk factor for cryptosporidiosis was postulated previously $(16,19)$. A total of 284 stool samples from Jordanian cattle, sheep, goats and chickens and 48 human stool samples were screened via 18S-qPCR and lectin locus-specific qPCR. The age of the humans sampled ranged from 10 months to 56 years and all were immunocompetent, hospitalized with a history of diarrhoea, abdominal pain and gastroenteritis. Cryptosporidium DNA was amplified in $37 / 284(13.0 \%)$ of animal and $4 / 48(8.3 \%)$ of human samples. Speciation revealed 6 different Cryptosporidium species, including C. xiaoi, C. andersoni, C. ryanae, C. parvum, and $C$. baileyi. The study identified several novel and previously existing subtypes for $C$. parvum isolates at the $60-\mathrm{kDa}$ glycoprotein (gp6o) obtained from humans and animals (18).

Another genetic study was done in 2017 and assessed the prevalence and genotypes of Cryptosporidium among paediatric oncology and non-oncology patients (10). In brief, Hijjawi et al. reported a statistically significantly higher prevalence of cryptosporidiosis $(14.4 \%$; 23 out of 160) among symptomatic paediatric oncology patients than symptomatic paediatric nononcology patients (5.1\%; 7 out of 137) using the modified acid-fast stain (10). All microscopy-positive stools were introduced for DNA extraction and were genotyped at species and subtype levels using the $18 \mathrm{~S}$ and gp6o loci, respectively. Cryptosporidium parvum was identified in all samples. Clustering of the same subtype (IIaA17G2R1) was noticed in almost all species from the 2 patient groups, suggesting the existence of a cryptosporidiosis outbreak during sampling. That study confirmed that chemotherapy and immunosuppression are considered risk factors for cryptosporidiosis as suggested previously (14).

Thelast published paper forcryptosporidiosisin Jordan was in October 2019 (12). This described the prevalence of cryptosporidiosis among haemodialysis patients from different areas. In that study a total of 133 stool samples were collected and screened for Cryptosporidium oocyst using formalin-ether concentration and a modified acid-fast staining technique. Cryptosporidium oocysts were recovered in 15/133 (11\%) of the patients with higher positivity incidence reported in males and in rural villages. The age of the patients ranged from 25 to 80 (mean 57.8; standard deviation 12.2) years and the most frequently reported symptoms were gastrointestinal symptoms. The study ensured the importance of modified acid-fast stain as a primary screening method and has recommended increasing the awareness of this parasite in this population group, and to include patients with kidney transplantation as well (12).

Reports for cryptosporidiosis from Jordan among different population groups relatively concurs with those from neighbouring and countries and other countries in the Region, which reflects the endemicity of this parasite and the need for more extensive epidemiological studies. Table 1 summarizes selected studies on cryptosporidiosis, highlighting the status of cryptosporidiosis in other Mediterranean countries and illustrating the diversity of diagnostic methods applied as well as the variation in the prevalence among these countries, all of which indicates the relative harmony between these reports and the results and methods reported in Jordan.

\section{Conclusion}

Cryptosporidiosis is still neglected in Jordan as indicated by the low number of studies over the last 3 decades and the prevalence is diverse depending the applied diagnostic test and the socioeconomic status.

\section{Recommendations}

Extensive studies on cryptosporidiosis in Jordan should be conducted and may include patients with the following inclusion criteria: kidney transplantation, autoimmune disorders, immunocompetent and immunocompromised children and adults, gastroenteritis, low socioeconomic status, from rural areas of different locations in Jordan, and people depending on groundwater for drinking. Modified acid-fast staining is informative and less expensive as a diagnostic screening tool in Jordan. Development, validation, and evaluation of Cryptosporidium-stool antigen immunoassay might be successful in increasing the specificity and sensitivity of detection and in reducing the costs in comparison with PCR. Finally, gp6o genotyping is important to investigate and track suspected common-source Cryptosporidium outbreaks.

Funding: None.

Competing interests: None declared. 


\section{Bilan de la situation de la cryptosporidiose en Jordanie}

\section{Résumé}

Contexte: Cryptosporidium est un parasite intestinal d'origine hydrique qui provoque des diarrhées et que l'on retrouve dans les pays à revenu faible et intermédiaire du monde entier. Des rapports provenant de pays méditerranéens ont mis en évidence les taux de prévalence de la cryptosporidiose chez les enfants appartenant à divers groupes d'âge, les personnes atteintes de cancer ou d'insuffisance rénale chronique et les personnes ayant subi une hémodialyse ou une greffe d'organe. La coloration acido-résistante modifiée d'une préparation de selles concentrées reste à ce jour le principal test diagnostique utilisé pour le dépistage de l'infection. Peu d'études sur la cryptosporidiose ont été réalisées en Jordanie au cours des trois dernières décennies.

Objectifs : La présente étude visait à examiner la situation de la cryptosporidiose en Jordanie et à suivre les mises à jour récentes concernant cette infection à protozoaire émergente dans différents groupes de population.

Méthodes : Dans la présente étude, une recherche a été réalisée en ligne sur les bases de données Google Scholar et PubMed. Les mots clés suivants ont été utilisés : Jordanie, cryptosporidiose et Cryptosporidium. L'objectif était de recenser les études réalisées sur ce parasite en Jordanie.

Résultats : Seuls neuf articles publiés entre 1994 et 2019 ont été recensés. Les éléments suivants ont été analysés : groupe de population, démographie, histoire clinique et outils diagnostiques utilisés.

Conclusion : La cryptosporidiose est encore négligée en Jordanie, comme l'indique le faible nombre d'études réalisées au cours des trois dernières décennies. La prévalence varie par ailleurs selon le test diagnostique utilisé et le statut socioéconomique.

$$
\begin{aligned}
& \text { حالة داء خَفِيات الأبواغ في الأردن: استعراض } \\
& \text { عبد الرحمن زعيتر } \\
& \text { الخلاصة }
\end{aligned}
$$

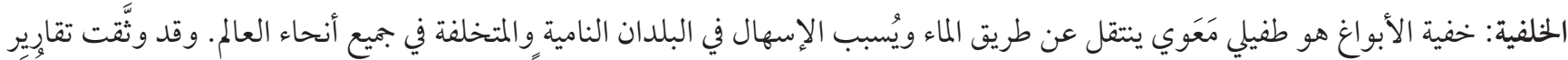

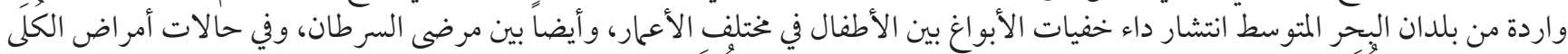

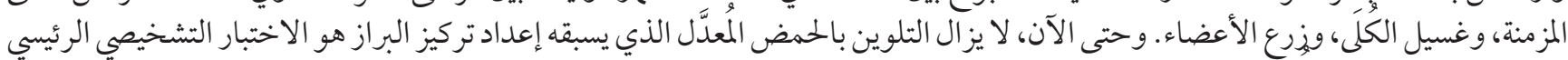

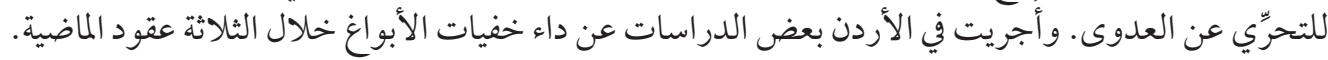

الأهداف: هدفت هذه الدراسة إلى بحث حالة داء خفيات الأبواغ في الأردن، وتتبع آخر مستجدات عدوى الأبح الأوالي الناشئة بين مختلف الفئات السكانية.

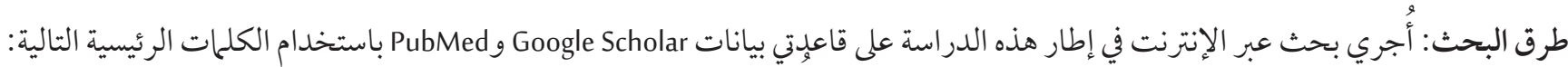

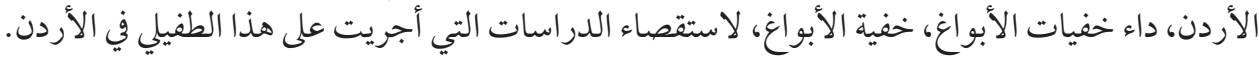

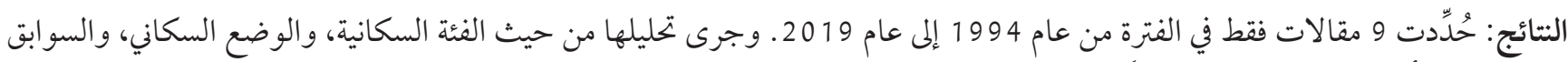

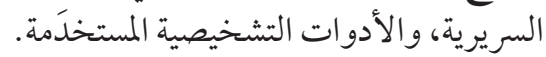

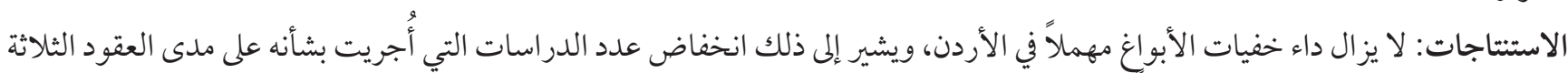

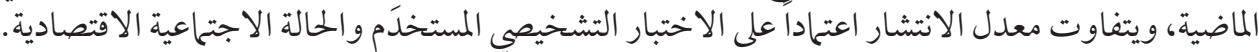




\section{References}

1. Ryan U, Fayer R, Xiao L. Cryptosporidium species in humans and animals: current understanding and research needs. Parasitol. 2014;141(13):1667-85. doi:10.1017/So031182014001085

2. Parghi E, Dash L, Shastri J. Evaluation of different modifications of acid-fast staining techniques and stool enzyme-linked immunosorbent assay in detecting fecal Cryptosporidium in diarrheic HIV seropositive and seronegative patients. Trop Parasitol. 2014;4(2):99-104. doi:10.4103/2229-5070.138537

3. Wang ZD, Liu Q, Liu HH, Li S, Zhang L, Zhao YK, et al. Prevalence of Cryptosporidium, microsporidia and Isospora infection in HIV-infected people: a global systematic review and meta-analysis. Parasit Vectors. 2018;11(1):28. doi:10.1186/s13071-017-2558-x

4. Checkley W, White AC, Jr, Jaganath D, Arrowood MJ, Chalmers RM, Chen XM, et al. A review of the global burden, novel diagnostics, therapeutics, and vaccine targets for cryptosporidium. Lancet Infect Dis. 2015;15(1):85-94. doi:10.1016/S1473-3099(14)70772-8

5. Centers for Disease Control and Prevention. Foodborne outbreak of diarrheal illness associated with Cryptosporidium parvumMinnesota, 1995. JAMA. 1996;276(15):1214. PMID:8849738

6. Addiss DG, Pond RS, Remshak M, Juranek DD, Stokes S, Davis JP. Reduction of risk of watery diarrhea with point-of-use water filters during a massive outbreak of waterborne Cryptosporidium infection in Milwaukee, Wisconsin, 1993. Am J Trop Med Hyg. 1996;54(6):549-53. doi:10.4269/ajtmh.1996.54.549

7. Centers for Disease Control and Prevention. Outbreaks of pseudo-infection with Cyclospora and Cryptosporidium-Florida and New York City, 1995. JAMA. 1997;277(18):1428-9. PMID:9145703

8. Pielok L, Nowak S, Kludkowska M, Frackowiak K, Kuszel L, Zmora P, et al. Massive Cryptosporidium infections and chronic diarrhea in HIV-negative patients. Parasitol Res. 2019;10.1007/s00436-019-06302-0. doi:10.1007/s00436-019-06302-0

9. Daniels ME, Smith WA, Jenkins MW. Estimating Cryptosporidium and Giardia disease burdens for children drinking untreated groundwater in a rural population in India. PLoS Negl Trop Dis. 2018;12(1):e0006231. doi:10.1371/journal.pntd.0006231

10. Hijjawi N, Zahedi A, Kazaleh M, Ryan U. Prevalence of Cryptosporidium species and subtypes in paediatric oncology and non-oncology patients with diarrhoea in Jordan. Infect Genet Evol. 2017;55:127-30. doi:10.1016/j.meegid.2017.08.033

11. Mohaghegh MA, Hejazi SH, Ghomashlooyan M, Kalani H, Mirzaei F, Azami M. Prevalence and clinical features of Cryptosporidium infection in hemodialysis patients. Gastroenterol Hepatol Bed Bench. 2017;10(2):137-42. PMID:28702138

12. Zueter AM, Hijjawi NS, Hamadeneh KN, Al-Sheyab MM, Hatamleh AM. Cryptosporidiosis among hemodialysis patients in Jordan: first preliminary screening surveillance. Trop Med Infect Dis. 2019;4(4):131. doi:10.3390/tropicalmed4040131

13. El-Kady AM, Fahmi Y, Tolba M, Hashim AA, Hassan AA. Cryptosporidium infection in chronic kidney disease patients undergoing hemodialysis in Egypt. J Parasit Dis. 2018;42(4):630-35. doi:10.1007/s12639-018-1046-3

14. Mahgoub E, Al Mahbashi A, Abdul Latif B. Cryptosporidiosis in children in a north Jordanian paediatric hospital. East Mediterr Health J. 2004;10(4-5):494-501.

15. Wang R-J, Li J-Q, Chen Y-C, Zhang L-X, Xiao L-H. Widespread occurrence of Cryptosporidium infections in patients with HIV/ AIDS: epidemiology, clinical feature, diagnosis, and therapy. Acta Trop. 2018;187:257-63. doi:10.1016/j.actatropica.2018.08.018

16. Nimri LF, Batchoun R. Prevalence of Cryptosporidium species in elementary school children. J Clin Microbiol. 1994;32(4):1040-2. PMID:8027307

17. Abo-Shehada M, Hindyia M, Saiah A. Prevalence of Cryptosporidium parvum in private drinking water cisterns in Bani-Kenanah district, northern Jordan. Int J Environ Health Res. 2004;14(5):351-8. DOI:10.1080/09603120400004030

18. Hijjawi N, Mukbel R, Yang R, Ryan U. Genetic characterization of Cryptosporidium in animal and human isolates from Jordan. Vet Parasitol. 2016;228:116-20. doi:10.1016/j.vetpar.2016.08.015

19. Nimri LF. Cyclospora cayetanensis and other intestinal parasites associated with diarrhea in a rural area of Jordan. Int Microbiol. 2003;6(2):131-35. doi:10.1007/s10123-003-0121-4

20. Nimri LF, Hijazi SS. Cryptosporidium. A cause of gastroenteritis in preschool children in Jordan. J Clin Gastroenterol. 1994;19(4):288-91. doi:10.1097/00004836-199412000-00005

21. Hijjawi N, Ng J, Yang R, Atoum MF, Ryan U. Identification of rare and novel Cryptosporidium GP6o subtypes in human isolates from Jordan. Exp Parasitol. 2010;125(2):161-4. doi:10.1016/j.exppara.2010.01.011

22. Saaed FM, Ongerth JE. Giardia and Cryptosporidium in children with diarrhea, Kufra, Libya, a North African migration route city. Int J Hyg Environ Health. 2019; 222: 840-6. doi:10.1016/j.ijheh.2019.04.006

23. Naguib D, El-Gohary AH, Roellig D, Mohamed AA, Arafat N, Wang Y, Feng Y, Xiao L. Molecular characterization of Cryptosporidium spp. and Giardia duodenalis in children in Egypt. Parasit Vector. 2018;11(1):403. doi:10.1186/s13071-018-2981-7

24. Osman M, El Safadi D, Cian A, Benamrouz S, Nourrisson C, Poirier P, Pereira B, Razakandrainibe R, Pinon A, Lambert C, Wawrzyniak I. Prevalence and risk factors for intestinal protozoan infections with Cryptosporidium, Giardia, Blastocystis and Dientamoeba among schoolchildren in Tripoli, Lebanon. PLoS Negl Trop Dis. 2016; 14;10(3):e0004496. doi:10.1371/journal.pntd.0004496

25. Hussein AS. Cryptosporidium parvum causes gastroenteritis epidemics in the Nablus region of Palestine. Trop Med Int Health. 2011;16(1):12-7. doi:10.1111/j.1365-3156.2010.02673.x

26. Gawad SS, Ismail MA, Imam NF, Eassa AH. Detection of Cryptosporidium spp. in Diarrheic Immunocompetent Patients in Beni-Suef, Egypt: Insight into Epidemiology and Diagnosis. Korean J Parasitol. 2018;56(2):113-9. doi:10.3347/kjp.2018.56.2.113 